\title{
VETERINARY SCIENCE AND VETERINARY MEDICINE
}

\section{Introduction}

Poultry farming is one of the most promising and fastest growing branches of business, and poultry is one of the world's largest stocks of domestic animals $[1,2]$. Thus, ensuring the biosecurity of birds is mandatory for economic prosperity and public health $[3,4]$. The main purpose of disinfection is to break the epizootic chain by influencing the transmission factor of the pathogen from the source of infection to the susceptible organism. The experimental preparation "Sukhodez" was developed for use as a dry disinfectant for livestock facilities, and in particular on poultry farms.

Preventive measures, including cleaning and disinfection, are fundamental steps for biosecurity programs and indispensable for maintaining high productivity on poultry and livestock facilities [5]. Proper use of universal disinfectants is a major part of the program to protect animals and humans [6].

Recent reports have shown that most poultry farms do not practice the basic principles of biosecurity [7]. Spraying disinfectants in barns and removing feces were the only sanitation schemes adopted in farms $[8,9]$. These disinfectants are used without regular inspection and evaluation of effectiveness, while the effectiveness of disinfectants is influenced by the composition, level of organic matter, humidity, temperature, dilution rate, $\mathrm{pH}$ and hardness of water and other factors [10]. In addition, the use of disinfectants without validation and evaluation can lead to high selective pressure, which will gradually reduce the sensitivity of organisms to the disinfectants used and even cross-resistance to antibiotics of health concern. Thus, inadequate sanitation procedures can be ineffective in controlling diseases, which reduces the productivity of birds [11]. Therefore, the evaluation of the effectiveness of disinfectants should be a priority for the selection of the appropriate disinfectant by minimizing the microbial.

When choosing a disinfectant for livestock, poultry farmers

\section{DETERMINATION OF ANTIMICROBIAL AND FUNGICIDAL PROPERTIES OF EXPERIMEN- TAL DISINFECTANT «SUKHODEZ»}

\author{
Tatiana Fotina ${ }^{1}$ \\ Dasha Slasten ${ }^{1}$ \\ Corresponding author \\ slasten_dasha@ukr.net
}

\section{Oleksii Fotin ${ }^{1}$}

1Department of Veterinary Examination, Microbiology, Zoohygiene and Safety and Quality of Livestock Products Sumy National Agrarian University

160 Herasyma Kondratieva str., Sumy, Ukraine, 40021

Abstract: The results of the study of antimicrobial and fungicidal properties of the experimental preparation "Sukhodez" against microorganisms E. coli, Salmonella enteritidis, Staphylococcus aureus and fungi Candida albicans in the laboratory are presented.

The aim of the research. To study the antimicrobial and fungicidal properties of powdered disinfectant and analyze the prospects for its further use in a set of anti-epizootic measures in particular in poultry farms.

Materials and methods. The research was conducted during 2021 at the Department of Veterinary Examination, Microbiology, Zoohygiene and Safety and Quality of Animal Products of the Faculty of Veterinary Medicine of Sumy National Agrarian University. Evaluation of bactericidal properties of the experimental agent "Sukhodez" was determined on museum strains of E. coli ATCC 25922, Salmonella enteritidis ATCC 13076 and Staphylococcus aureus ATCC 6538, fungicidal properties were studied on fungi Candida albicans. All cultures were standardized to $109 \mathrm{CFU} / \mathrm{cm}^{3}$.

Results. It is established that as a result of the conducted researches at studying preparation "Sukhodez" antimicrobic properties, it had high efficiency concerning action on strains of both gram-positive and gram-negative bacteria. It had a detrimental effect on bacteria when applied to concrete at an exposure of 1 hour with a rate of $75 \mathrm{mg}$ per $1 \mathrm{~m}^{2}$, and had the same effect as when applied to a wooden surface, where it expressed antimicrobial action at a rate of $50 \mathrm{mg} / \mathrm{m}^{2}$ after 4 hours. When determining the fungicidal properties, it was found that when exposed to 5 hours, the preparation "Sukhodez" had an effect on study contaminated objects with a rate of $50 \mathrm{mg} / \mathrm{m}^{2}$, and with a rate of $75 \mathrm{mg} / \mathrm{m}^{2}$ inhibited the growth of fungi for 1 hour.

Conclusions. It was found that the most sensitive to the preparation "Sukhodez" were the culture of Salmonella enteritidis - at a rate of $25 \mathrm{~g} / \mathrm{m}^{2}$ and action on concrete and wooden surfaces, the disinfectant inhibited the growth of the culture when exposed to 5 hours, and at a rate of $50 \mathrm{~g} / \mathrm{m}^{2}$ - for 2 years. Staphylococcus aureus was the most stable bacterial culture, so at a rate of $50 \mathrm{~g} / \mathrm{m}^{2}$ on concrete and wood surfaces, bacterial growth was inhibited for 4 and 5 hours, respectively. At the same time, in the study of fungicidal properties, "Sukhodez" showed a fungicidal effect on Candida albicans when applied to a concrete surface at a rate of $50 \mathrm{mg} / \mathrm{m}^{2}$ for 3 hours, when applied to a wooden surface - for 4 hours.

In general, at a rate of $75 \mathrm{~g} / \mathrm{m}^{2}$, "Sukhodez" has an instant bactericidal and fungicidal effect on bacteria and fungi applied to concrete and wooden surfaces.

Keywords: disinfection, antimicrobial and fungicidal activity, disinfectant, laboratory, microorganisms, poultry, "Sukhodez". should pay attention to a number of characteristics that must have a disinfectant, and in particular its effect on the condition, health, behaviour of animals and birds [12]. Numerous engineering standards are strictly adhered to limit the spread of pathogens in animal housing [13]. Chemical disinfectants are often the first line of defense against these pathogens and are a must when choosing the right product.

Thus, disinfection of livestock and poultry facilities is one of the highest priority on the path to a healthy and prosperous economy. Widely used chemical disinfectants for broiler premises include available chlorine, ozone, Quaternary ammonium salt and glutaraldehyde. Different disinfectants used for large-scale disinfection of broiler houses work through different mechanisms, and therefore, the effectiveness of their disinfection also varies. Chlorine-containing compounds (sodium dichloroisocyanurate, sodium hypochlorite, bleaching powder, chlorine dioxide, etc.) are widely used as disinfectants in livestock and poultry [14].

Due to the fact that a significant number of disinfectants used are toxic, exhibit immunosuppressive properties for animals and poultry, it is still relevant for modern veterinary medicine to develop new, safe and effective means of disinfection $[15,16]$.

Given the above, the development of disinfectants based on nanotechnology, the components of which have a wide range of action (antibacterial, antiviral, antifungal action), high biological activity and low toxicity, is an indisputable alternative to traditional disinfectants [17].

Many disinfectants are used on farms by aerosol splicing, which is difficult to do in the presence of animals and poultry. Also using aerosol products, in addition to heavy and costly use, the premises accumulate excess moisture. Therefore, we offer current disinfection of premises with dry biocidal products. These disinfectants by their properties are environmentally friendly, have a loose composi- 
tion, the vast majority of light color, pleasant aroma, and most importantly - most have an adsorbent effect. They are effective for the destruction and control of many bacteria, viruses, fungi, parasites, larvae of flies. In addition, they improve the quality of litter, reduce ammonia content and humidity in livestock premises [18]. Thus, the development of new highly effective, cheap, multifunctional, as well as environmentally friendly disinfectants, is an important and priority area of research in the field of veterinary sanitation [19].

Powdered disinfectants are convenient to use not only when they can be used in the presence of animals and birds, but also due to their partially adsorbing action [20]. As a result: the property of the drug to absorb moisture from the litter prevents many diseases associated with excessively wet litter (dermatitis, coccidiosis and some infections). It is especially important that reducing the release of ammonia, hydrogen sulfide and other harmful gases into the atmosphere of livestock and poultry significantly improves the health of animals and poultry, reduces treatment costs, more complete and efficient use of feed, improves working conditions for staff. All this gives grounds to reduce the environmental tax on agricultural enterprises as a result of the fact that emissions of ammonia and other pollutants are significantly reduced [21].

The aim of the research. To study antimicrobial and fungicidal properties of experimental powdered disinfectant and to analyze prospects of its further application in a complex of antiepizootic measures in particular on poultry farms.

\section{Materials and methods}

Evaluation of bactericidal properties of the experimental agent "Sukhodez" was determined on museum strains of E. coli ATCC 25922, Salmonella enteritidis ATCC 13076 and Staphylococcus aureus ATCC 6538, fungicidal properties were studied on fungi Candida albicans.

The composition of the active substance of the experimental disinfectant "Sukhodez" (\%): chloramine - 0.2; thymol - 0.1; copper sulfate -2.0 ; iron sulfate -1.0 ; calcium sulfate dihydrate - 45.0; zeolite - 42.0; kaolin - 9.6; flavoring - 0.1.

All cultures were standardized to $10^{9} \mathrm{CFU} / \mathrm{cm}^{3}$ [22]. The concentration of bacterial cells in $1 \mathrm{~cm}^{3}$ of the working suspension was determined using the bacterial turbidity standard. After the tested exposures, the effect of the chemicals was neutralized with sodium hydroxide. Suspension of each culture was sprayed on concrete and wooden surfaces of test objects at the rate of $5 \mathrm{~cm}^{3} / 100 \mathrm{~cm}^{2}$.

An ovalbumin solution was used to determine the effect of protein load on the level of antimicrobial activity. To do this, after drying the suspension, the test objects were treated with a solution of ovalbumin $-20 \mathrm{mg} / \mathrm{cm}^{3}$ (protein protection) and applied the preparation "Sukhodez" at the rates of consumption: $25,50,75$ and $100 \mathrm{~g} / \mathrm{m}^{2}$. As a control, the infected test object was treated with boiled tap water. After 1, 2, 3, 4, 5 and 6 hours of exposure, washes from test objects were performed on an area of $10 \times 10 \mathrm{~cm}\left(100 \mathrm{~cm}^{2}\right)$. For which samples were taken with sterile cotton swabs, chemicals were neutralized and additionally centrifuged twice for $30 \mathrm{~min}$ at $2500 \mathrm{rpm}$. The precipitate after the second centrifugation was diluted with $1 \mathrm{~cm}^{3}$ of sterile saline and sown in $0.5 \mathrm{~cm} 3$ on KODA medium (objects contaminated with E. coli) and $\mathrm{BCH}$ and Saburo agar (objects contaminated with $C$. albicans). The cultures were incubated at $37{ }^{\circ} \mathrm{C}$ for 2 days. Accounting for the bactericidal and fungicidal action of the experimental agent was carried out by changing the color of the medium and the presence or absence of growth on nutrient media in the experiment and control. The test was considered positive when the color of the KODA medium changed from green to yellow, when the $\mathrm{BCH}$ was cloudy and there was growth on Saburo medium.

\section{Results}

When studying the effectiveness of the experimental disinfectant "Sukhodez" on the pathogens of the most common infectious and fungal diseases that were on the test objects (concrete, wood) in direct contact (Tables 1, 2), it was found that the experimental preparation "Sukhodez" was effective against a controlled spectrum of pathogens of bacterial diseases and had an adsorbing effect.

Table 1

The effectiveness of the experimental preparation "Sukhodez" on the cells of E. coli bacteria ATCC 25922, Salmonella enteritidis ATCC 13076 and Staphylococcus aureus ATCC 6538, which were applied to concrete

\begin{tabular}{|c|c|c|c|c|c|c|c|c|c|c|c|c|}
\hline \multirow{3}{*}{$\begin{array}{l}\text { Exposi- } \\
\text { tion }\end{array}$} & \multicolumn{12}{|c|}{$\begin{array}{l}\text { Test cultures and norms of consumption of prepa- } \\
\text { ration, } \mathrm{g} / \mathrm{m}^{2}\end{array}$} \\
\hline & \multicolumn{4}{|c|}{$\begin{array}{c}\text { Salmonella en- } \\
\text { teritidis ATCC } \\
13076\end{array}$} & \multicolumn{4}{|c|}{$\begin{array}{c}\text { Staphylococcus } \\
\text { aureus ATCC } \\
6538\end{array}$} & \multicolumn{4}{|c|}{$\begin{array}{l}\text { Escherichia coli } \\
\text { ATCC } 25922\end{array}$} \\
\hline & 25 & 50 & 75 & 100 & 25 & 50 & 75 & 100 & 25 & 50 & 75 & 100 \\
\hline $60 \mathrm{~min}$ & $\checkmark$ & $\checkmark$ & $x$ & $x$ & $\checkmark$ & $\checkmark$ & $x$ & $x$ & $\checkmark$ & $\checkmark$ & $x$ & $x$ \\
\hline $120 \mathrm{n}$ & $\checkmark$ & $\checkmark$ & $x$ & $x$ & $\checkmark$ & $\checkmark$ & $x$ & $x$ & $\checkmark$ & $\checkmark$ & $x$ & $x$ \\
\hline $180 \mathrm{~min}$ & $\checkmark$ & $x$ & $x$ & $x$ & $\checkmark$ & $\checkmark$ & $x$ & $x$ & $\checkmark$ & $\checkmark$ & $x$ & $x$ \\
\hline $240 \mathrm{~min}$ & $\checkmark$ & $x$ & $x$ & $x$ & $\checkmark$ & $x$ & $x$ & $x$ & $\checkmark$ & $x$ & $x$ & $x$ \\
\hline $300 \mathrm{~min}$ & $x$ & $x$ & $x$ & $x$ & $\checkmark$ & $x$ & $x$ & $x$ & $\checkmark$ & $x$ & $x$ & $x$ \\
\hline $360 \mathrm{~min}$ & $x$ & $x$ & $x$ & $x$ & $\checkmark$ & $x$ & $x$ & $x$ & $x$ & $x$ & $x$ & $x$ \\
\hline
\end{tabular}

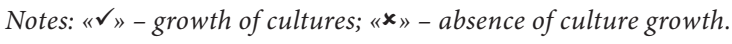

At a consumption rate of $75 \mathrm{~g} / \mathrm{m}^{2}$, uniform sprinkling of test objects contaminated with suspensions of cultures: E. coli ATCC 25922, Salmonella enteritidis ATCC 13076 and Staphylococcus aureus ATCC 6538, within the first hour after application provided $100 \%$ disinfection. A smaller dose of this tool $\left(50 \mathrm{~g} / \mathrm{m}^{2}\right)$ also provided the same efficiency for 3-4 hours.

Table 2

The effectiveness of the experimental preparation "Sukhodez" on the cells of E. coli bacteria ATCC 25922, Salmonella enteritidis ATCC 13076 and Staphylococcus aureus ATCC 6538, which were applied to the wood

\begin{tabular}{|c|c|c|c|c|c|c|c|c|c|c|c|c|}
\hline \multirow{3}{*}{$\begin{array}{l}\text { Exposi- } \\
\text { tion }\end{array}$} & \multicolumn{12}{|c|}{$\begin{array}{l}\text { Test cultures and norms of consumption of prepa- } \\
\text { ration, } \mathrm{g} / \mathrm{m}^{2}\end{array}$} \\
\hline & \multicolumn{4}{|c|}{$\begin{array}{c}\text { Salmonella en- } \\
\text { teritidis ATCC } \\
13076\end{array}$} & \multicolumn{4}{|c|}{$\begin{array}{c}\text { Staphylococcus } \\
\text { aureus ATCC } \\
6538\end{array}$} & \multicolumn{4}{|c|}{$\begin{array}{l}\text { Escherichia coli } \\
\text { ATCC } 25922\end{array}$} \\
\hline & 25 & 50 & 75 & 100 & 25 & 50 & 75 & 100 & 25 & 50 & 75 & 100 \\
\hline $60 \mathrm{n}$ & $\checkmark$ & $\checkmark$ & $x$ & $x$ & $\checkmark$ & $\checkmark$ & $x$ & $x$ & $\checkmark$ & $\checkmark$ & $x$ & $x$ \\
\hline $120 \mathrm{~min}$ & $\checkmark$ & $\checkmark$ & $x$ & $x$ & $\checkmark$ & $\checkmark$ & $x$ & $x$ & $\checkmark$ & $\checkmark$ & $x$ & $x$ \\
\hline $180 \mathrm{~min}$ & $\checkmark$ & $\checkmark$ & $x$ & $x$ & $\checkmark$ & $\checkmark$ & $x$ & $x$ & $\checkmark$ & $\checkmark$ & $x$ & $x$ \\
\hline $240 \mathrm{~min}$ & $\checkmark$ & $x$ & $x$ & $x$ & $\checkmark$ & $\checkmark$ & $x$ & $x$ & $\checkmark$ & $\checkmark$ & $x$ & $x$ \\
\hline $300 \mathrm{~min}$ & $x$ & $x$ & $x$ & $x$ & $\checkmark$ & $x$ & $x$ & $x$ & $\checkmark$ & $x$ & $x$ & $x$ \\
\hline $360 \min$ & $x$ & $x$ & $x$ & $x$ & $\checkmark$ & $x$ & $x$ & $x$ & $x$ & $x$ & $x$ & $x$ \\
\hline
\end{tabular}

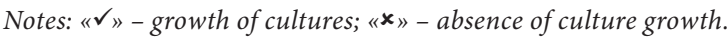

When determining the fungicidal properties, it was proved that the experimental preparation "Sukhodez" has a pro- 


\section{VETERINARY SCIENCE AND VETERINARY MEDICINE}

nounced fungicidal effect at a rate of $75 \mathrm{~g} / \mathrm{m}^{2}$ and an exposure of 1 hour and $50 \mathrm{~g} / \mathrm{m}^{2}$ at an exposure of 4 hours (Table 3 ).

\section{Table 3}

The effectiveness of the experimental preparation "Sukhodez" on the cells of the fungi Candida albicans, which were applied to test objects

\begin{tabular}{|c|c|c|c|c|c|c|c|c|}
\hline \multirow{4}{*}{$\begin{array}{c}\text { Exposi- } \\
\text { tion }\end{array}$} & \multicolumn{8}{|c|}{ Test objects } \\
\hline & \multicolumn{4}{|c|}{ wood } & \multicolumn{4}{|c|}{ concrete } \\
\hline & \multicolumn{8}{|c|}{ norms of consumption of preparation, $\mathrm{g} / \mathrm{m}^{2}$} \\
\hline & 25 & 50 & 75 & 100 & 25 & 50 & 75 & 100 \\
\hline $60 \mathrm{~min}$ & $\checkmark$ & $\checkmark$ & $x$ & $x$ & $\checkmark$ & $\checkmark$ & $x$ & $x$ \\
\hline $120 \mathrm{~min}$ & $\checkmark$ & $\checkmark$ & $x$ & $x$ & $\checkmark$ & $\checkmark$ & $x$ & $x$ \\
\hline $180 \mathrm{~min}$ & $\checkmark$ & $\checkmark$ & $x$ & $x$ & $\checkmark$ & $\checkmark$ & $x$ & $x$ \\
\hline $240 \mathrm{~min}$ & $\checkmark$ & $\checkmark$ & $x$ & $x$ & $\checkmark$ & $x$ & $x$ & $x$ \\
\hline $300 \mathrm{~min}$ & $x$ & $x$ & $x$ & $x$ & $\checkmark$ & $x$ & $x$ & $x$ \\
\hline $360 \mathrm{~min}$ & $x$ & $x$ & $x$ & $x$ & $x$ & $x$ & $x$ & $x$ \\
\hline
\end{tabular}

Notes: « $\checkmark$ - growth of cultures; $« \boldsymbol{x}_{\Downarrow}-$ absence of culture growth.

\section{Discussion of research results}

Dry disinfection plays an important role in the system of veterinary and sanitary measures on farms, because in contrast to aerosol and wet disinfection, dry disinfectants could be used in the presence of animals and poultry [23].

In this regard, a new experimental preparation "Sukhodez" was developed.

The antibacterial and fungicidal properties of "Sukhodez" when exposed to test surfaces contaminated with culture suspensions were studied: E. coli ATCC 25922, Salmonella enteritidis ATCC 13076 and Staphylococcus aureus ATCC 6538, fungi Candida albicans. However, it was found that when used on concrete and wooden surfaces at a rate of $75 \mathrm{~g} / \mathrm{m}^{2}$, the preparation has a detrimental effect on microorganisms E. coli, Salmonella enteritidis, Staphylococcus aureus and fungi Candida albicans [24].
On the basis of the carried-out laboratory researches the optimum indicators of exposure and expenses of the working means "Sukhodez", from calculation of weight on $\mathrm{m}^{2}$ of the area of the room which is subject to disinfection are developed and established.

Summarizing the obtained scientific results, it should be noted that our research was aimed at studying the antimicrobial and fungicidal properties of the experimental preparation "Sukhodez" which should be used in livestock facilities in the presence of animals.

Study limitations. The limitation of the research is to conduct experiments in the laboratory on museum strains that are different from the field, so the concentration of the drug may vary slightly, depending on the level of contamination.

Prospects for further research. Further work will be aimed at study and testing the results of virucidal properties of dry disinfectant "Sukhodez".

\section{Conclusions}

Thus it is proved that the experimental drug "Sukhodez" at a consumption rate of $75 \mathrm{~g} / \mathrm{m}^{2}$ has a pronounced bactericidal and fungicidal action against grams of negative, grams of positive microorganisms and fungi at an exposure of 1 hour, a similar effect has a consumption rate of $50 \mathrm{~g} / \mathrm{m}^{2}$ at exposure for 3-4 hours when applying test cultures on both concrete and wood.

\section{Conflict of interests}

The authors declare there is no conflict of interests.

\section{Financing}

The research is part of the research work of the Department of Veterinary Examination, Microbiology, Zoohygiene and Safety and Quality of Livestock Products of Sumy NAU on the topic "Development and improvement of veterinary and sanitary measures to prevent, treat, increase productivity and resistance of animals" (state registration number 0119U101389).

\section{References}

1. Hamid, M. A., Rahman, M. A., Ahmed, S., Hossain, K. M. (2016). Status of Poultry Industry in Bangladesh and the Role of Private Sector for its Development. Asian Journal of Poultry Science, 11 (1), 1-13. doi: http://doi.org/10.3923/ajpsaj.2017.1.13

2. Hemen, J. T., Johnson, J. T., Ambo, E. E., Ekam, V. S., Odey, M. O., Fila, W. A. (2012). Multi-antibiotic resistance of some Gram negative bacterial isolates from poultry litters of selected farms in Benue State. International Journal of Science and Technology, 2 (8), 543-547.

3. Abstracts from the 5th International Conference on Prevention \& Infection Control (ICPIC 2019) (2019). Antimicrobial Resistance and Infection Control, 8 (Suppl 1), 148. doi: http://doi.org/10.1186/s13756-019-0567-6

4. Wadud, S., Michaelsen, A., Gallagher, E., Parcsi, G., Zemb, O., Stuetz, R., Manefield, M. (2012). Bacterial and fungal community composition over time in chicken litter with high or low moisture content. British Poultry Science, 53 (5), 561-569. doi: http://doi.org/10.1080/00071668.2012.723802

5. De Castro Burbarelli, M. F., do Valle Polycarpo, G., Deliberali Lelis, K., Granghelli, C. A., Carão de Pinho, A. C., Ribeiro Almeida Queiroz, S. et. al. (2017). Cleaning and disinfection programs against Campylobacter jejuni for broiler chickens: productive performance, microbiological assessment and characterization. Poultry Science, 96 (9), 3188-3198. doi: http://doi.org/ $10.3382 / \mathrm{ps} / \mathrm{pex} 153$

6. Hafez, H. M., Attia, Y. A. (2020). Challenges to the Poultry Industry: Current Perspectives and Strategic Future After the COVID-19 Outbreak. Frontiers in Veterinary Science, 7. doi: http://doi.org/10.3389/fvets.2020.00516

7. Barua, H., Biswas, P. K., Olsen, K. E. P., Shil, S. K., Christensen, J. P. (2013). Molecular Characterization of Motile Serovars of Salmonella enterica from Breeder and Commercial Broiler Poultry Farms in Bangladesh. PLoS ONE, 8 (3), e57811. doi: http:// doi.org/10.1371/journal.pone.0057811

8. Rimi, N. A., Sultana, R., Muhsina, M., Uddin, B., Haider, N., Nahar, N. et. al. (2017). Biosecurity Conditions in Small Commercial Chicken Farms, Bangladesh 2011-2012. EcoHealth, 14 (2), 244-258. doi: http://doi.org/10.1007/s10393-017-1224-2 


\section{TECHNOLOGY TRANSFER: INNOVATIVE SOLUTIONS IN MEDICINE, 2021}

9. Stringfellow, K., Anderson, P., Caldwell, D., Lee, J., Byrd, J., McReynolds, J. et. al. (2009). Evaluation of disinfectants commonly used by the commercial poultry industry under simulated field conditions. Poultry Science, 88 (6), 1151-1155. doi: http://doi.org/ 10.3382/ps.2008-00455

10. Islam, K. N., Monira, K. N., Sultana, R., Azharul, I. M. (2007). The effect of Timsen and Ambicide as disinfectant on hatchability traits of Kasila broiler parents eggs in Bangladesh. Livestock Research for rural development, 19, 44.

11. McDonnell, G., Russell, A. D. (1999). Antiseptics and Disinfectants: Activity, Action, and Resistance. Clinical Microbiology Reviews, 12 (1), 147-179. doi: http://doi.org/10.1128/cmr.12.1.147

12. Muhandiramlage, G. K., McWhorter, A. R., Chousalkar, K. K. (2020). Chlorine Induces Physiological and Morphological Changes on Chicken Meat Campylobacter Isolates. Frontiers in Microbiology, 11. doi: http://doi.org/10.3389/fmicb.2020.00503

13. Campagna, M. V., Faure-Kumar, E., Treger, J. A., Cushman, J. D., Grogan, T. R., Kasahara, N., Lawson, G. W. (2016). Factors in the Selection of Surface Disinfectants for Use in a Laboratory Animal Setting. Journal of the American Association for Laboratory Animal Science: JAALAS, 55 (2), 175-188.

14. Pattnaik, S., Subramanyam, V., Kole, C. (2016). Antibacterial and antifungal activity often essential oils in vitro. Microbios., 86 (349), 237-246.

15. Papp, S., Kimmerl, K., Gatz, J., Laue, M., Grunow, R., Kaspari, O. (2020). Evaluation of Sporicidal Disinfectants for the Disinfection of Personal Protective Equipment During Biological Hazards. Health Security, 18 (1), 36-48. doi: http://doi.org/ 10.1089/hs.2019.0128

16. Golovko, A. M., Pinchuk, N. G., Fotina, T. I., Klishchova, Z. E. (2019). Determination of bactericidal properties of the drug "Saroflox" in relation to museum test cultures of microorganisms. Scientific Messenger of LNU of Veterinary Medicine and Biotechnologies, 21 (95), 89-92. doi: http://doi.org/10.32718/nvlvet9516

17. Garcês, A. P. J. T., Afonso, S. M. S., Chilundo, A., Jairoce, C. T. S. (2016). Evaluation of different litter materials for broiler production in a hot and humid environment: 2. Productive performance and carcass characteristics. Tropical Animal Health and Production, 49 (2), 369-374. doi: http://doi.org/10.1007/s11250-016-1202-7

18. Atapattu, N. S. B. M., Lakmal, L. G. E., Perera, P. W. A. (2017). Effects of two litter amendments on air NH3 levels in broiler closed-houses. Asian-Australasian Journal of Animal Sciences, 30 (10), 1500-1506. doi: http://doi.org/10.5713/ajas.16.0873

19. Paliy, A., Zavgorodniy, A., Stegniy, B., Gerilovych, A. (2015). A Study of the Efficiency of Modern Domestic Disinfectants in the System of TB Control Activities. Agricultural Science and Practice, 2 (2), 26-31. doi: http://doi.org/10.15407/agrisp2.02.026

20. Pepper, C.-M., Dunlop, M. W. (2021). Review of litter turning during a grow-out as a litter management practice to achieve dry and friable litter in poultry production. Poultry Science, 100 (6), 101071. doi: http://doi.org/10.1016/j.psj.2021.101071

21. Ku, T. S. N., Walraven, C. J., Lee, S. A. (2018). Candida auris: Disinfectants and Implications for Infection Control. Frontiers in Microbiology, 9. doi: http://doi.org/10.3389/fmicb.2018.00726

22. Filonov, B. (2003). Methods for checking and assessing the antimicrobial activity of disinfectants and antiseptics: instructions for use. Hygiene and Sanitation, 51 (50).

23. Gilbert, P., Moore, L. E. (2005). Cationic antiseptics: diversity of action under a common epithet. Journal of Applied Microbiology, 99 (4), 703-715. doi: http://doi.org/10.1111/j.1365-2672.2005.02664.x

24. Sevilla-Navarro, S., Catalá-Gregori, P., García, C., Cortés, V., Marin, C. (2020). Salmonella Infantis and Salmonella Enteritidis specific bacteriophages isolated form poultry faeces as a complementary tool for cleaning and disinfection against Salmonella. Comparative Immunology, Microbiology and Infectious Diseases, 68, 101405. doi: http://doi.org/10.1016/j.cimid.2019.101405

Received date 14.09.2021

Accepted date 21.10.2021

(c) The Author(s) 2021

Published date 28.10.2021

This is an open access article under the Creative Commons CC BY license

How to cite: Fotina, T., Slasten, D., Fotin, O. (2021). Determination of antimicrobial and fungicidal properties of experimental disinfectant «Sukhodez». Technology transfer: innovative solutions in medicine, 35-38. doi: https://doi.org/10.21303/2585-6634.2021.002124 